\title{
Solid Angioleiomyoma
}

National Cancer Institute

\section{Source}

National Cancer Institute. Solid Angioleiomyoma. NCI Thesaurus. Code C49110.

A morphologic variant of angioleiomyoma characterized by the presence of numerous small, slit-like vascular channels. 